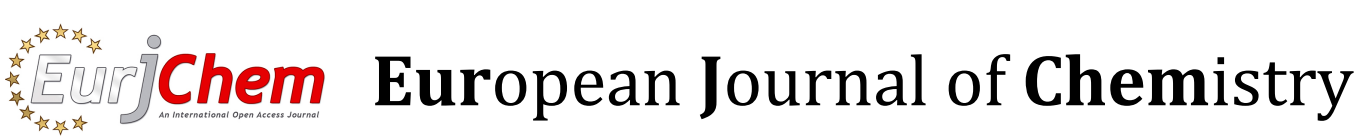

Check for updates

\section{A highly sensitive and selective spectrofluorimetric method for the determination of molybdenum at pico-trace levels in various matrices using $N$-(pyridin-2-yl)-quinoline-2-carbothioamide}

\author{
Muhammad Jamaluddin Ahmed (D) 1,*, Ayesha Afrin (D) 2 and Muhammad Emdadul Haque (D) 1 \\ ${ }^{1}$ Laboratory of Analytical Chemistry, Department of Chemistry, University of Chittagong, Chittagong, 4331, Bangladesh \\ pmjahmed55@gmail.com (M.J.A.), emdadulh994@gmail.com (M.E.H.) \\ 2 Department of Applied Chemistry and Chemical Engineering, University of Chittagong, Chittagong, 4331, Bangladesh \\ aafrin.aec@cu.ac.bd (A.A.) \\ * Corresponding author at: Laboratory of Analytical Chemistry, Department of Chemistry, University of Chittagong, Chittagong, 4331, Bangladesh. \\ e-mail:mjahmed83@cu.ac.bd (M.J.Ahmed).
}

\section{RESEARCH ARTICLE}

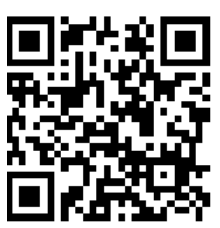

10.5155/eurjchem.12.1.1-12.2031

Received: 19 August 2020

Received in revised form: 14 November 2020

Accepted: 20 December 2020

Published online: 31 March 2021

Printed: 31 March 2021

\section{KEYWORDS}

\section{Food samples}

Biological samples

Spectrofluorimetry

Environmental samples

Molybdenum determination

$\mathrm{N}$-(Pyridin-2-yl)-quinoline-2-carbothioamide

\begin{abstract}
A new spectrofluorimetric reagent $N$-(pyridin-2-yl)-quinoline-2-carbothioamide (PQTA) has been synthesized and characterized. A very simple, ultra-sensitive, and highly selective, and non-extractive new spectrofluorimetric method for the determination of molybdenum at pico-trace levels using PQTA has been developed. This novel fluorimetric reagent PQTA, becomes oxidized in a slightly acidic (0.0025-0.05 $\mathrm{M} \mathrm{H}_{2} \mathrm{SO}_{4}$ ) solution with molybdenum (VI) in absolute ethanol to produce a highly fluorescent oxidized product $\left(\lambda_{\mathrm{ex}}=300 \mathrm{~nm} ; \lambda_{\mathrm{em}}=377\right.$ $\mathrm{nm})$. Constant and maximum fluorescence intensities were observed over a wide range of acidity (0.0025-0.0500 $\mathrm{M} \mathrm{H}_{2} \mathrm{SO}_{4}$ ) for the period between $2 \mathrm{~min}$ and $24 \mathrm{~h}$. Linear calibration graphs were obtained for $0.001-600 \mu \mathrm{g} / \mathrm{L}$ of Mo having a detection limit of $0.15 \mathrm{ng} / \mathrm{L}$; the quantification limit of the reaction system was found to be $1.5 \mathrm{ng} / \mathrm{L}$ and the RSD was $0-2 \%$. A large excess of over 60 cations, anions, and complexing agents like chloride, phosphate, azide, tartrate, oxalate, and SCN- etc. do not interfere in the determination. The developed method was successfully used in the determination of molybdenum in several Certified Reference Materials (Alloys, steel, serum, bovine liver, drinking water, soil, and sediments) as well as in some environmental waters (Potable and polluted), biological fluids (Human blood, urine, hair, and milk), soil samples and food samples (Vegetables, rice, and wheat) solutions containing both molybdenum (VI) and molybdenum (V) ions. The results of the proposed method for assessing biological, food and vegetable samples were comparable with ICP-OES and AAS were found to be in excellent agreement.
\end{abstract}

Cite this: Eur. J. Chem. 2021, 12(1), 1-12

Journal website: www.eurjchem.com

\section{Introduction}

Molybdenum is essential to all living organisms, especially plants, animals, and microorganisms, because of its important role in enzymatic redox reactions and its specific geochemical behavior [1]. In addition, molybdenum is also widely used as a trace material for particular steel in industrial products. Molybdenum plays an important role in plant nitrogen metabolism and constitutes nitrogener as an enzyme allowed to convert nitrogen in air to ammonia at the start of protein synthesis [2]. A high concentration of molybdenum in soil causes abnormal growth of some plants. In mammals, molybdenum is a component of certain metalloproteinase's, including xanthenesoxidize, sulphite oxidize and aldehyde oxidaze $[3,4]$. In terms of function, molybdoenzymes catalyze the oxidation and sometimes reduction of certain small molecules in the process of regulating nitrogen, sulfur, and carbon [5]. Furthermore, an excess of this element becomes harmful to ruminants, since the adsorption of copper by the liver is depressed. In contrast, molybdenum deficiency eventually results in a diminished number of flowers on plants and severe disturbances in the formation of reproductive organs and especially in the development of pollen [6]. Molybdenum can also affect self-purification processes of natural water. At about $5 \mathrm{mg} / \mathrm{L}$, it inhibits biochemical selfpurification processes. An even higher content of molybdenum in water prevents the growth of some microorganisms [7]. Owing to these two contrary effects, the precise and accurate determination of molybdenum in environmental samples is essential. Therefore, several analytical methods have been developed for the determination of molybdenum in various environmental matrices [8].

Many methods have been proposed for the determination of molybdenum which includes spectrophotometry [9], sophisticated techniques, such as Anodic Striping Voltammetry [10], ICP-AES [11], ICP-MS [12] and ICP-OES [13-15], HPLC [16] as well as AAS $[17,18]$ has been used for the determination of total molybdenum. ICP-MS and ICP-OES costly and are not used or routine analysis in developing countries like Bangladesh. AAS is sensitive but suffers from interference of matrices. However, spectrofluorimetry is essentially a trace analysis technique and is one of the most powerful tools in chemical 


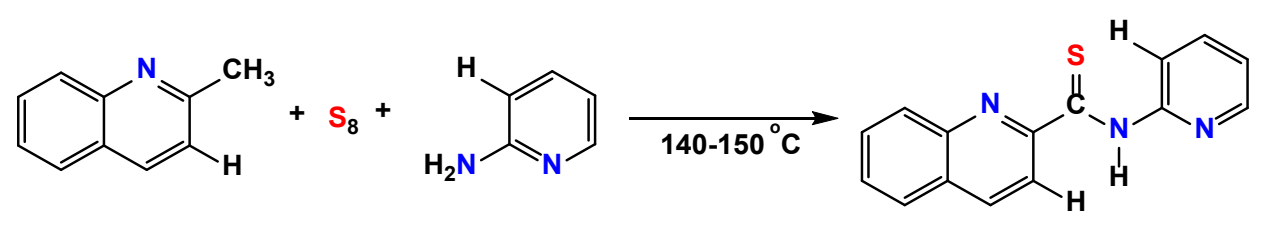

Scheme 1. Synthesis of $N$-(pyridin-2-yl)-quinoline-2-carbothioamide (PQTA).

analysis. This method still has the advantages of being simple and without requiring expensive or complicated test equipment. For this reason, a wide variety of spectrofluorimetric methods for the determination of molybdenum have been developed [19-52]. Several authors have reported on the extractive spectrofluorimetric determination of molybdenum using complexes formed with a variety of reagents [19-52]. In most of the methods [19-52] cited above, molybdenum forms soluble or insoluble complexes with reagents with various organic solvents for spectrofluorimetric determination. Most of these reagents are expensive and non-recoverable. Most of the organic solvents which were used are carcinogenic. However, interferences from coexisting ions, especially for some rare earth ions, $\mathrm{Fe}^{3+}$ and $\mathrm{PO}_{4}{ }^{3-}$ are always faced in the existing methods.

The goal of the present work was to develop a simpler direct spectrofluorimetric method for the pico-trace determination of molybdenum. In the search for a more sensitive reagent, in this work, a new reagent was synthesized according to the method of Porter [53] and an oxidation reaction of $\mathrm{N}$ (pyridin-2-yl)-quinoline-2-carbothioamide; with Mo (VI) and forms an intensely fluorescent oxidized product. Although PQTA has been reported to be a spectrofluorimetric reagent for Se (IV) [54], Mn (VII) [55], As (V) [56], Ce (IV) [57], but has not previously been used for the spectrofluorimetric determination of molybdenum. The method possesses distinct advantages over existing methods [19-52] (Table 1) with respect to sensitivity, selectivity, range of determination, simplicity, speed, $\mathrm{pH}$ /acidity range, thermal stability, accuracy, precision and ease of operation. The method is based on the oxidative reaction of nonfluorescent PQTA in a slightly acidic $(0.0025$ $0.0500 \mathrm{M} \mathrm{H}_{2} \mathrm{SO}_{4}$ ) solution with Mo (VI) in presence of ethanol to produce a highly fluorescent oxidized product, followed by a direct measurement of the fluorescence intensity in an aqueous solution at room temperature. Oxidation is very rapid and no extraction is required. With suitable masking, the reaction can be made to be highly selective and the reagent blank solutions do not show any fluorescence. The proposed method is more superior to the existing reported methods [19-52] in respect to sensitivity, selectivity, range of determination, simplicity, and rapidity which are shown in Table 1.

\section{Experimental}

\subsection{Apparatus}

A Shimadzu (Kyoto, Japan) (Model-RF-5301PC) Spectrofluorophotometer with $1 \mathrm{~cm}$ quartz cells were used and a Jenway (England, UK) (Model-3010) pH meter with a combination of electrodes were used for measurements of the fluorescence intensity and $\mathrm{pH}$, respectively. The calibration and linearity of the instrument were frequently checked with standard quinine sulphate $(10 \mathrm{mg} / \mathrm{L})$. A Shimadzu (Kyoto, Japan) (Model-9800) Inductively Coupled Plasma-Optical Emission Spectrometer (ICP-OES), $[\lambda=418 \mathrm{~nm}$, plasma gas flow rate $=15 \mathrm{~L} / \mathrm{min}, \mathrm{LOD}=1 \mu \mathrm{g} / \mathrm{L}$ of Mo, RF Power $=1400 \mathrm{~W}$, Nebulizer gas flow rate $=1-10 \mathrm{~L} / \mathrm{min}$ ] and a Shimadzu (Kyoto, Japan) (Model: AA7000) atomic absorption spectrophotometer equipped with a microcomputer-controlled air-acetylene flame was used to compare all of the results. A Shimadzu (Kyoto,
Japan) (Model-1800) double beam UV/VIS spectrophotometer was used for the measurement of absorbance.

\subsection{Synthesis and characterization of the reagent}

$N$-(Pyridin-2-yl)quinoline-2-carbothioamide was synthesized according to the method of Portar [53]. The mixtures containing 2-aminopyridin, quinaldine, and sulphur powder in the molar ratio of 2:1:1.5 were mixed and refluxed for 6 hours in a 250 mLround bottom flask fitted with a bulb condenser under controlled temperature $\left(140-150{ }^{\circ} \mathrm{C}\right)$ at $1 \mathrm{~atm}$ pressure over the oil bath. The reaction mixture was kept overnight. The thio-compound was filtered and crystallized using petroleum ether $60-80{ }^{\circ} \mathrm{C}$ to give a bright yellow crystalline (needle shaped) solid. The compound was recrystallized from ethanol and was kept under vacuum $(0.1 \mathrm{~mm}$ of $\mathrm{Hg}$ ) for 24 hours. Yield of the product was $70 \%$. The melting point of the synthesized compound was $155 \pm 2{ }^{\circ} \mathrm{C}$ (Lit. $155 \pm 1{ }^{\circ} \mathrm{C}[54,55]$ ), which indicated the purity of PQTA. The structure of the reagent is shown in Scheme 1 .

\subsection{Reagents and solutions}

All chemicals used were of analytical reagent grade of the highest purity available. High-purity absolute ethanol and highpurity deionized water were used throughout. High-purity water was obtained by passing tap water through the cellulose absorbent and on mixed-bed ion exchange columns, followed by distillation in a Corning AG-11 unit. Glass vessels were cleaned by soaking in acidified solutions of $\mathrm{KMnO}_{4}$ or $\mathrm{K}_{2} \mathrm{Cr}_{2} \mathrm{O}_{7}$ followed by washing with concentrated $\mathrm{HNO}_{3}$ and rinsed several times with high purity deionized water. Stock solutions and environmental water samples ( $1000 \mathrm{~mL}$ each) were kept in polypropylene bottles containing $1 \mathrm{~mL}$ concentrated $\mathrm{HNO}_{3}$. More rigorous contamination control was used when the molybdenum levels in the specimens were low.

\subsubsection{PQTA solution}

The reagent solution was prepared by dissolving the requisite amount $(0.0100 \mathrm{~g})$ of PQTA in a known volume (10 $\mathrm{mL}$ ) of absolute ethanol. A freshly prepared reagent solution $\left(3.77 \times 10^{-3} \mathrm{M}, 0.10 \%\right.$ PTQA solution) was used whenever required.

\subsubsection{Molybdenum (VI) standard solution}

A $100 \mathrm{~mL}$ amount of stock solution $\left(1 \mathrm{mg} / \mathrm{mL}, 1.49 \times 10^{-3} \mathrm{M}\right)$ of hexavalent molybdenum was prepared by dissolving 184.0 mg of purified grade (Merck pro-analysis grade, purity 99.6\%) ammonium molybdate tetra-hydrate, $\left(\mathrm{NH}_{4}\right)_{6} \mathrm{Mo}_{7} \mathrm{O}_{24} \cdot 4 \mathrm{H}_{2} \mathrm{O}$, (J. T. Baker, super special grade) in doubly distilled deionized water and subsequently standardized gravimetrically by the 8hydroxyquinolinol (Oxine) [58]. More dilute standard solutions were prepared by appropriate dilution of aliquots from the stock solution with deionized water as and when required. A freshly standardized solution was always used. 
Table 1. Summary of reviews on the existing spectrofluorimetric methods for the determination of molybdenum.

\begin{tabular}{|c|c|c|c|c|}
\hline \multicolumn{5}{|c|}{ Bathophenanthrolinedisulphonate [37] } \\
\hline Solvent & Ethanol & Beer's Law & $0.01-1.0$ & Remarks \\
\hline Medium & Aqueous & Detection limit & 5 & i) Less sensitive. \\
\hline $\mathrm{pH}$ & $3.0-3.7$ & RSD \% & 3 & ii) $\mathrm{pH}$ dependent. \\
\hline$\lambda_{\mathrm{ex}}: \lambda_{\mathrm{em}}$ & $288: 445$ & & & iii) Less selective due to much interference. \\
\hline Interference & $\mathrm{Cu}, \mathrm{Ni}, \mathrm{Co}, \mathrm{Fe}, \mathrm{V}$ & & & iv) Quench of fluorimetric \\
\hline \multicolumn{5}{|l|}{ Porphyrine [38] } \\
\hline Solvent & $\mathrm{CCl}_{4}$ & Beer's Law & $10-1000$ & Remarks \\
\hline Medium & Organic & Detection limit & 15 & i) Less sensitive. \\
\hline $\mathrm{pH}$ & 3.5 & RSD \% & 5 & ii) $\mathrm{pH}$ dependent. \\
\hline$\lambda_{\mathrm{ex}}: \lambda_{\mathrm{em}}$ & $330: 393$ & & & iii) Time consuming. \\
\hline Interference & Many & & & iv) Solvent extractive. \\
\hline \multicolumn{5}{|l|}{ Carminic acid [39] } \\
\hline Solvent & Pyridine & Beer's Law & $0.1-0.9$ & Remarks \\
\hline Medium & Organic & Detection limit & 6 & i) Solvent extractive. \\
\hline $\mathrm{pH}$ & $5.2^{2}$ & RSD \% & 3 & ii) Less sensitive. \\
\hline$\lambda_{\mathrm{ex}}: \lambda_{\mathrm{em}}$ & $560: 590$ & & & iii) Less selective due to much interference. \\
\hline Interference & Many & & & \\
\hline \multicolumn{5}{|l|}{ Alizarin Red S [31] } \\
\hline Solvent & Chloroform & Beer's Law & $0.1-1.0$ & Remarks \\
\hline Medium & Organic & Detection limit & 5 & i) Solvent extractive. \\
\hline $\mathrm{pH}$ & 6.3 & RSD \% & 2 & ii) Less sensitive. \\
\hline$\lambda_{\mathrm{ex}}: \lambda_{\mathrm{em}}$ & $478: 623$ & & & iii) Less selective due to much interference. \\
\hline Interference & $\mathrm{Cu}^{2+}, \mathrm{Fe}^{2+}, \mathrm{Fe}^{3+}$, EDTA, etc. & & & \\
\hline \multicolumn{5}{|l|}{ L-Ascorbic acid [24] } \\
\hline Solvent & $\mathrm{H}_{2} \mathrm{O}_{2}$ & Beer's Law & $0-30$ & Remarks \\
\hline Medium & Organic & Detection limit & 4 & i) Lengthy and time consuming. \\
\hline $\mathrm{pH}$ & 3.2 & RSD \% & 5 & ii) Less sensitive. \\
\hline$\lambda_{\mathrm{ex}}: \lambda_{\mathrm{em}}$ & $350: 425$ & & & iii) Less selective due to much interference. \\
\hline Interference & $\mathrm{Fe}^{3+}, \mathrm{Cr}^{4+}, \mathrm{V}^{4+}, \mathrm{V}^{5+}, \mathrm{Cu}^{2+}$, etc. & & & \\
\hline \multicolumn{5}{|c|}{ 2-Hydroxy-1-naphthaldehydene-p-aminotoluene (HNA) [23] } \\
\hline Solvent & Ethanol & Beer's Law & $0-20$ & Remarks \\
\hline Medium & Aqueous & Detection limit & 6 & i) Less sensitive. \\
\hline $\mathrm{pH}$ & 6.8 & RSD \% & 5 & ii) Time consuming. \\
\hline$\lambda_{\mathrm{ex}}: \lambda_{\mathrm{em}}$ & $300: 380$ & & & iii) Less selective due to much interference. \\
\hline Interference & Many, $\mathrm{Ga}^{3+}, \mathrm{In}^{3+}, \mathrm{Tl}^{3+}$, etc. & & & \\
\hline \multicolumn{5}{|c|}{$N$-(Pyridin-2-yl)-quinoline-2-carbothioamide [Present method] } \\
\hline Solvent & Ethanol & Beer's Law & $0.001-600$ & Remarks \\
\hline Medium & Aqueous & Detection limit & 0.2 & i) Ultra-sensitive. \\
\hline Acidity $\left(\mathrm{H}_{2} \mathrm{SO}_{4}\right)$ & $0.0025-0.05$ & RSD \% & $0-2$ & ii) Highly selective. \\
\hline$\lambda_{\mathrm{ex}}: \lambda_{\mathrm{em}}$ & $300: 377$ & & & iii) Pico-trace level determination $(\mathrm{pg} / \mathrm{mL})$. \\
\hline Interference & None, using suitable maskin & & & iv) Fluorescence is stable for $24 \mathrm{~h}$. \\
\hline
\end{tabular}

* Units: $\lambda_{\text {ex: }} \lambda_{\text {em }}(\mathrm{nm})$, Beer's Law ( $\left.\mu \mathrm{g} / \mathrm{L}\right)$, and Detection limit ( $\left.\mu \mathrm{g} / \mathrm{L}\right)$.

\subsubsection{Molybdenum (V) stock solutions}

A $100 \mathrm{~mL}$ amount of stock solution $\left(1 \mathrm{mg} / \mathrm{mL}, 1.04 \times 10^{-2} \mathrm{M}\right)$ of pentavalent molybdenum was prepared by dissolving 284.7 mg of molybdenum (V) chloride ( $\mathrm{MoCl}_{5}$ ), (Aldrich A.C.S. proanalysis grade) in double distilled deionized water containing 1-2 $\mathrm{mL}$ of nitric acid $(1+1)$. Aliquot of this solution was standardized by gravimetrically using 8-hydroxyquinolinol (Oxine) [58,59]. More dilute standard solutions were prepared from this stock solution as and when required.

\subsubsection{Potassium dichromate solution}

A $100 \mathrm{~mL}$ amount of stock solution ( $0.1 \mathrm{~N})$ was prepared by dissolving $490.3 \mathrm{mg}$ of finely powdered $\mathrm{K}_{2} \mathrm{Cr}_{2} \mathrm{O}_{7}$ (Merck) in 100 $\mathrm{mL}$ deionized water.

\subsubsection{Ammonium persulphate solution}

Ammonium persulphate solution $(2 \%, w: v)$ (A.C.S-grade, $99 \%$ pure) was freshly prepared by dissolving $2 \mathrm{~g}$ in $100 \mathrm{~mL}$ of deionized water.

\subsubsection{Tartrate solution}

A $100 \mathrm{~mL}$ stock solution of tartrate $(0.01 \%, w: v)$ was prepared by dissolving $10 \mathrm{mg}$ of A.C.S.-grade (99\% pure) potassium sodium tartrate tetra-hydrate in $100 \mathrm{~mL}$ deionized water.

\subsubsection{Aqueous ammonia solution}

A $100 \mathrm{~mL}$ solution of an aqueous ammonia solution was prepared by diluting $10 \mathrm{~mL}$ concentrated $\mathrm{NH}_{4} \mathrm{OH}(28-30 \%$, A.C.S.-grade) to $100 \mathrm{~mL}$ with deionized water. The solution was stored in a polypropylene bottle.

\subsubsection{EDTA solution}

A $100 \mathrm{~mL}$ stock solution of ethylenediaminetetraacetic acid (EDTA) $(0.01 \%, w: v)$ was prepared by dissolving $10 \mathrm{mg}$ A.C.S.grade ( $\geq 99 \%$ pure) EDTA as disodium salt dehydrate in $100 \mathrm{~mL}$ deionized water.

\subsubsection{Other solutions}

Solutions of a large number of inorganic ions and complexing agents were prepared from their AnalaR grade or equivalent grade water-soluble salts (or oxides and carbonates in hydrochloric acid); those of niobium, tantalum, titanium, zirconium and hafnium were specially prepared from their corresponding oxides (Specpure, Johnson Matthey) according to the recommended procedures of Mukherji [60]. In the case of insoluble substances, special dissolution methods were adopted [61].

\subsection{Procedure}

To 0.1-1.0 mL of a neutral aqueous solution containing 0.01 $6000 \mathrm{ng}$ of molybdenum (VI) in a $10 \mathrm{~mL}$ calibrated flask was 


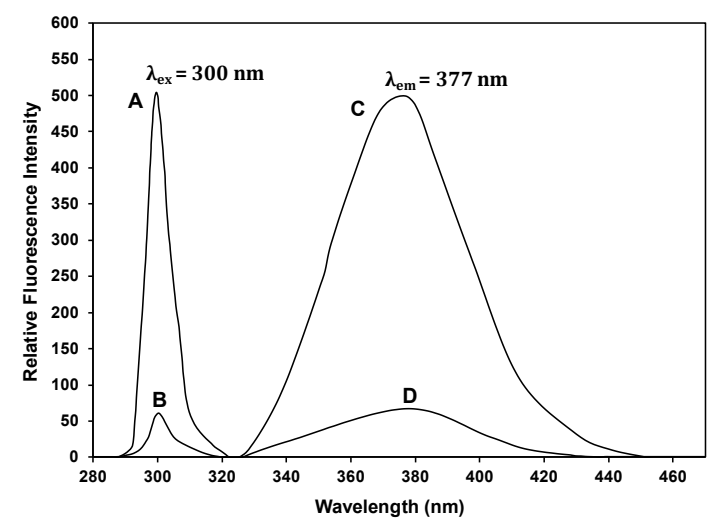

Figure 1. Spectra A and B are the excitation spectra $\left(\lambda_{\text {ex }}=300 \mathrm{~nm}\right)$ of MoVI-PQTA system and reagent blank, respectively; C and D are the corresponding emission spectra $\left(\lambda_{\mathrm{em}}=377 \mathrm{~nm}\right)$ in aqueous solution. Band width: Ex. slit-1.5, Em. Slit-1.5, Sensitivity: High.

mixed with a 1:70-1:270 fold molar excess (preferably $1.0 \mathrm{~mL}$ ) of $3.77 \times 10^{-3} \mathrm{M}$ of $\mathrm{N}$-(pyridin-2-yl)quinoline-2-carbothioamide (PQTA) reagent solution followed by the addition of $0.5-2 \mathrm{~mL}$ (preferably $1 \mathrm{~mL}$ ) of $0.025 \mathrm{M}$ of sulfuric acid. The solution was mixed well and allowed to stand for $5 \mathrm{~min}$, after which $2 \mathrm{~mL}$ of absolute ethanol was added and the mixture was diluted to the mark with deionized water. The fluorescence intensity of the system was measured at $377 \mathrm{~nm}$ against a corresponding reagent blank, prepared concurrently, keeping the excitation wavelength maximum at $300 \mathrm{~nm}$ and the instrument set the same. The molybdenum content in an unknown sample was determined using a concurrently prepared calibration graph.

\subsection{Sample collection and preservation}

\subsubsection{Environmental samples}

Water and soil samples were collected in polythene bottles from different places of Bangladesh. After collection, $\mathrm{HNO}_{3}(1$ $\mathrm{mL} / \mathrm{L}$ ) was added as a preservative.

\subsubsection{Live subject statement}

We were not aiming to carry out detailed human studies, but some samples from individuals were used in our study and as such we abided by all necessary procedures and regulations and our University gave consent. University of Chittagong, Bangladesh, is committed to the protection and safety of human subjects involved in research.

\subsubsection{Blood, urine, and milk samples}

Blood and urine samples were collected in polythene bottles from effected persons of Chittagong Medical College Hospital, Bangladesh. Milk sample was collected from a Bangladeshi lactating mother. Immediately after collection, they were stored in a salt-ice mixture and later, at the laboratory, were at $-20^{\circ} \mathrm{C}$.

\subsubsection{Soil samples}

Soil samples were collected from different locations of Bangladesh. Samples were dried in air and homogenized with a mortar.

\subsubsection{Food samples}

Food samples (Rice, wheat, fruits, and vegetables) were collected from the local market of Chittagong. After collection, the samples of fruits and vegetables) were stored in a refrigerator for preservation. Samples of rice and wheat were used as dry conditions and homogenized with a mortar.

\section{Results and discussion}

\subsection{Excitation and emission spectra}

Mo (VI) fluoresces strongly in PQTA solution when irradiated with ultraviolet light. The excitation and emission spectra of the fluorescent Mo (VI)-PQTA in $0.0025 \mathrm{M}$ sulfuric acid medium was recorded using the spectrofluorophotometer. The excitation and emission maxima wavelength were at 300 $\mathrm{nm}$ and $377 \mathrm{~nm}$, respectively. The reagent blank exhibited negligible fluorescence, despite having a wavelength maximum in the same region. In all instances, measurements were made against the reagent blank. The spectra are shown in Figure 1.

\subsection{Optimization of some parameters on the fluorescence intensity}

\subsubsection{Effect of solvent}

Because PQTA is insoluble in water, an organic solvent was used for the system. Of the various solvents, chloroform, benzene, carbon tetrachloride, $n$-butanol, isobutanol, ethanol, 1,4-dioxane and $\mathrm{N}, \mathrm{N}$-dimethylformamide were tested for the system, and ethanol was found to be the best solvent for the system. The effect of ethanol on the fluorescence intensity was studied and no adverse effect was observed over a wide range $(20-80 \%)$ of ethanol concentrations. A concentration of $20 \%$ $(v: v)$ ethanol in the final volume was sufficient to prevent any precipitation or turbidity and to allow accurate measurements. Therefore, a $20 \%(v: v)$ ethanol solution was used in the recommended procedure.

\subsubsection{Effect of acidity}

The oxidation reaction was conducted in acid medium to avoid the formation of precipitation of molybdenum. In order to determine the most suitable acid for the reaction, different acids (Nitric, sulfuric, hydrochloric, and phosphoric acids) were studied. However, sulfuric acid was found to be the best acid than any other mineral acids for the system. The fluorescence intensity was at maximum and constant when $10 \mathrm{~mL}$ of solution $\left(10 \mu \mathrm{g} / \mathrm{L}\right.$ of $\left.\mathrm{Mo}^{\mathrm{VI}}\right)$ contained $0.5-2.0 \mathrm{~mL}$ of $0.025 \mathrm{M}$ sulfuric acid at room temperature $\left(25 \pm 5{ }^{\circ} \mathrm{C}\right)$. Outside this range of acidity, the fluorescence intensity decreased. The optimum acidity range in the final solution is therefore 0.0025-0.0500 M (preferably $0.0025 \mathrm{M}$ ) $\mathrm{H}_{2} \mathrm{SO}_{4}$. Therefore, $1 \mathrm{~mL}$ of $0.025 \mathrm{M}$ sulfuric acid solution was used for all subsequent measurements. 
Table 2. Selected analytical parameters for the optimization experiments.

\begin{tabular}{|c|c|c|}
\hline Parameters & Studied range & Selected value \\
\hline Excitation wavelength maximum, $\lambda_{\mathrm{ex}}(\mathrm{nm})$ & $200-700$ & 300 \\
\hline Emission wavelength maximum, $\lambda_{\mathrm{em}}(\mathrm{nm})$ & $200-700$ & 377 \\
\hline Solvent, amount of absolute ethanol (mL) & $0-8$ & 2-8 (preferably 2) \\
\hline Acidity, $\mathrm{H}_{2} \mathrm{SO}_{4}(\mathrm{M})$ & $0.0001-0.5$ & $0.0025-0.05$ (preferably 0.0025 ) \\
\hline $\mathrm{pH}$ & $1.0-3.0$ & $1.3-1.7$ (preferably 1.5 ) \\
\hline Time & $0-72$ & $1 \mathrm{~min}-24 \mathrm{~h}$ (preferably 2 ) \\
\hline Temperature $\left({ }^{\circ} \mathrm{C}\right)$ & $10-80$ & $15-40$ (preferably $25 \pm 5$ ) \\
\hline Reagent (fold molar excess, R:M) & $1: 1-1: 500$ & 1:70-1:270 (preferably $1: 100$ ) \\
\hline Linear range $(\mu \mathrm{g} / \mathrm{L})$ & $0.0001-1000$ & $0.001-600$ \\
\hline Detection limit (ng/L) & $0.001-10.0$ & 0.15 \\
\hline Limit of quantification (ng/L) & $0.01-100$ & 1.5 \\
\hline Reproducibility (\% RSD) & $0-10$ & $0-2$ \\
\hline Regression co-efficient $\left(\mathrm{R}^{2}\right)$ & $0.9992-0.9999$ & 0.9998 \\
\hline
\end{tabular}

Regression co-efficient $\left(\mathrm{R}^{2}\right)$

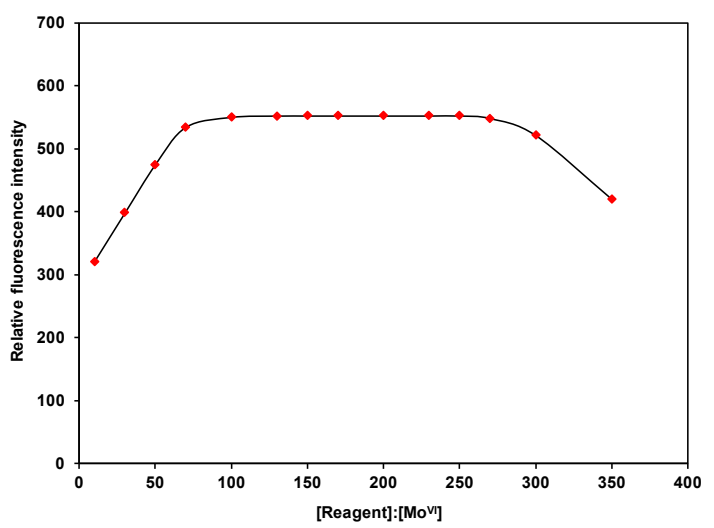

Figure 2. Effect of reagent ration (PQTA: Mo(VI) molar concentration) on the fluorescence of Mo(VI)-PQTA system.

\subsubsection{Effect of temperature}

The influence of temperature was studied between 10-80 ${ }^{\circ} \mathrm{C}$. Temperature effect is not pronounced between 10 and $80^{\circ} \mathrm{C}$, so room temperature $\left(25 \pm 5^{\circ} \mathrm{C}\right)$ is recommended for all subsequent measurements.

\subsubsection{Effect of time}

The reaction is instantaneous. The MovI-PQTA system attained maximum and constant fluorescence intensity immediately (within $5 \mathrm{~min}$ ) after dilution of the solution to the final volume, which then remained strictly unaltered for $24 \mathrm{~h}$ at room temperature $\left(25 \pm 5^{\circ} \mathrm{C}\right)$.

\subsubsection{Effect of reagent concentration}

The intensities of the fluorescence of a series of solutions containing a constant amount of Mo (VI) with varying amounts of PQTA were measured in order to establish the optimum concentration of PQTA. It was found that the fluorescence intensity increases at first as the PQTA concentration rises and reaches a maximum, but further addition of PQTA may hardly affect the intensity, even PQTA is more times concentrated than Mo (VI) (Figure 2). It was observed that at $10 \mu \mathrm{g} / \mathrm{L} \mathrm{Mo} \mathrm{(VI)metal}$ and the reagent molar ratios of 1:70-1:270 produced a constant fluorescence intensity of the oxidized product. Outside this range of reagents, the fluorescence intensity gets decreased. At different Mo(VI) concentrations ( 0.5 and $1 \mu \mathrm{g} / \mathrm{L})$, the effect of varying the reagent concentration was similar. For all subsequent measurements, $1.0 \mathrm{~mL}$ of $3.77 \times 10^{-3} \mathrm{M}$ PQTA reagent was added.

\subsubsection{Effect of metal concentration}

The effect of Mo (VI) solution was investigated by carrying out the reaction using $1 \mathrm{~mL}$ of Mo (VI) solution of different concentrations ranging from $0.001-1000 \mu \mathrm{g} / \mathrm{L}$. It was found that the relative fluorescence intensity increased by increasing the concentration of Mo (VI) up to $600 \mu \mathrm{g} / \mathrm{L}$, but higher concentration has a negative effect on the values of the relative fluorescence intensity.

\subsubsection{Calibration curves (Beer's law)}

The calibration graphs for the determination of Mo (VI) were constructed under optimum conditions. The well-known equation for spectrofluorimetric analysis in dilute solutions derived from Beer's law. The effect of metal concentration was studied over $0.001-1000 \mu \mathrm{g} / \mathrm{L}$ distributed in six different sets (0.001-0.01, 0.01-0.1, 0.1-1, 1-10, 10-100 and 100-1000 $\mu \mathrm{g} / \mathrm{L}$ ) for convenience of measurement. The fluorescence intensity was linear over a wide range $1 \mathrm{pg} / \mathrm{mL}$ to $600 \mu \mathrm{g} / \mathrm{L}$ for 0.001 $600 \mu \mathrm{g} / \mathrm{L}$ of molybdenum (VI) at the excitation wavelength at $300 \mathrm{~nm}$ and emission wavelength at $377 \mathrm{~nm}$ representing six linear graphs (0.001-0.01, 0.01-0.1, 0.1-1.0, 1.0-10, 10-100 and $100-600 \mu \mathrm{g} / \mathrm{L})$. Of the six calibration graphs, one showed the limit of the linearity range is shown in Figure 3; the remaining five were straight-line graphs passing through the origin $\left(R^{2}=\right.$ 0.9998). The limit of detection and limit of quantization were found to be 0.15 and $1.5 \mathrm{ng} / \mathrm{L}$, respectively. The selected analytical parameters obtained from the optimization experiments are summarized in Table 2.

\subsubsection{Effect of foreign ions}

In order to apply the proposed method to the determination of the concentration of Mo (VI) in the real sample, the effect of some co-existing species was investigated using $10 \mu \mathrm{g} / \mathrm{L}$ of molybdenum (VI). More than 60 anions, cations, and complexing agents were studied individually to investigate their effect on the determination of $10 \mu \mathrm{g} / \mathrm{L}$ of molybdenum (VI). 
Table 3. The tolerance limits of foreign ions a, tolerance ratio [species $\left.(\mathrm{x}) / \mathrm{Mov}^{\mathrm{VI}}(w: w)\right]$

\begin{tabular}{|c|c|c|c|}
\hline Species x & Tolerance ratio $\mathrm{x} / \mathrm{Mo}(w: w)$ & Species $\mathrm{x}$ & Tolerance ratio $\mathrm{x} / \mathrm{Mo}(w: w)$ \\
\hline Ammonium & 1000 & Iron (III) & $500^{b}$ \\
\hline Aluminum & 1000 & Lead (II) & 1000 \\
\hline Azide & 1000 & Magnesium & 1000 \\
\hline Arsenic (III) & 1000 & Manganese (II) & 1000 \\
\hline Arsenic (V) & $100 \mathrm{~b}$ & Manganese (VII) & $300^{c}$ \\
\hline Ascorbic acid & 1000 & Mercury (II) & 1000 \\
\hline Antimony & 1000 & Molybdenum (V) & $100^{c}$ \\
\hline Barium & 1000 & Nitrate & 1000 \\
\hline Bromide & 1000 & Nickel & 1000 \\
\hline Bismuth (III) & 1000 & Oxalate & 1000 \\
\hline Beryllium (II) & 1000 & Potassium & 1000 \\
\hline Calcium & 1000 & Selenium (IV) & $100^{c}$ \\
\hline Chloride & 1000 & Selenium (VI) & 1000 \\
\hline Cobalt (II) & 1000 & Silver & 1000 \\
\hline Cobalt (III) & 1000 & Sodium & 1000 \\
\hline Copper (I) & 1000 & Strontium & 1000 \\
\hline Copper (II) & 1000 & Sulfate & 1000 \\
\hline Chromium (III) & 1000 & Tellurium (IV) & 1000 \\
\hline Chromium (IV) & $100^{c}$ & Tellurium (VI) & 1000 \\
\hline Cadmium & 1000 & Titanium (IV) & 1000 \\
\hline Carbonate & 1000 & Tartrate & 1000 \\
\hline Cesium & 1000 & Thallium (III) & $500^{b}$ \\
\hline Citrate & 1000 & Thiocyanate & 1000 \\
\hline Cerium (III) & 1000 & Thiourea & 1000 \\
\hline Cerium (IV) & $100 \mathrm{~b}$ & Tungsten (VI) & 1000 \\
\hline Cyanide & 1000 & Tin (II) & 1000 \\
\hline EDTA & 1000 & Tin (IV) & 1000 \\
\hline Fluoride & 1000 & Uranium (VI) & 1000 \\
\hline Iodide & 1000 & Vanadium (V) & $500^{b}$ \\
\hline Iron (II) & 1000 & Zinc & 1000 \\
\hline
\end{tabular}

a Tolerance limit was defined as the ratio that causes less than \pm 5 percent interference.

a With $10 \mathrm{mg} / \mathrm{L}$ tartrate.

c With $10 \mathrm{mg} / \mathrm{L}$ EDTA.

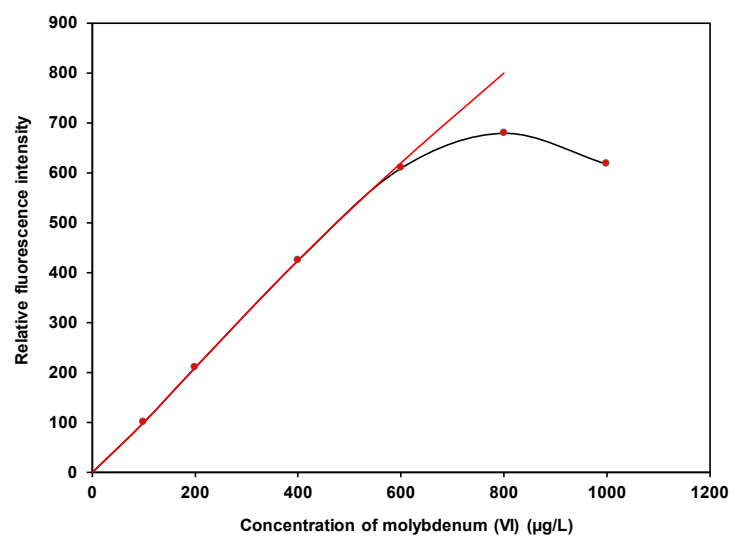

Figure 3. Calibration graph, 100-600 $\mu \mathrm{g} / \mathrm{L}$ of molybdenum (VI), Bandwidth: Ex. Slit: 1.5, Em. Slit: 1.5, Sensitivity: High.

The criterion for interference [62] was a fluorescence intensity value varying by more than $\pm 5 \%$ from the expected value for molybdenum alone. The results are summarized in Table 3. As can be seen, a large number of ions have no significant effect on the determination of molybdenum. The most serious interference was from Se (IV), $\mathrm{Cr}$ (VI), and Mn (VII). Most of the ions were tolerated over 1000 exceeds. Ascorbic acid, oxalate, citrate, tartrate, EDTA, and fluoride ions, etc. were tolerated over 5000 folds. In order to eliminate the interference of Se (IV), Cr (VI), and Mn (VII) ions, EDTA and tartrate can be used as masking agents, respectively $[63,64]$. A 100 -fold excess of Se (IV), $\mathrm{Cr}$ (VI), and Mn (VII) ions could be masked with EDTA and tartrate, respectively. During the interference studies, if a precipitated was formed, it was removed by centrifugation. Strong reducing agents such as tin (II), chloride, iron (II), sulfate, hydroxylamine, hydrochloride, and sodium azide, which would otherwise reduce molybdenum (VI), undergo oxidation during the treatment of the molybdenum (V) solution with persulphate and hence are not a problem [65]. The amount mentioned is not the tolerance limit but the actual amount studied. However, for those ions whose tolerance limits have been studied, their tolerance ratios are mentioned in Table 3.

\subsubsection{Precision and accuracy}

The precisions of the present method were proved by measuring 10 solutions of the same sample (each analyzed at least five times). The relative standard deviation $(\mathrm{n}=5)$ was 0 $2 \%$ for $0.01-6000 \mathrm{ng}$ of molybdenum (VI) in $10 \mathrm{~mL}$, indicating that this method is highly precise and reproducible (Table 2). The detection limit (3s of the blank) and limit of quantization (10 times of detection limit) for molybdenum (VI) were found to be 0.15 and $1.5 \mathrm{ng} / \mathrm{L}$, respectively. The method was also tested by analyzing several synthetic mixtures containing molybdenum (VI) and diverse ions (Table 4). The results for total molybdenum were in excellent agreement with certified values (Table 5). The reliability of the procedure was tested by recovery studies. 
Table 4. Determination of molybdenum in some synthetic mixtures.

\begin{tabular}{|c|c|c|c|c|}
\hline \multirow[t]{2}{*}{ Sample } & \multirow[t]{2}{*}{ Composition of mixtures $(\mu \mathrm{g} / \mathrm{L})$} & \multicolumn{3}{|c|}{ Molybdenum ( $\mu \mathrm{g} / \mathrm{L})$} \\
\hline & & Added & Found $(n=5)^{a}$ & Recovery \pm SD (\%) ${ }^{b}$ \\
\hline \multirow[t]{2}{*}{$\overline{\mathrm{A}}$} & Mo (VI) & 1.0 & 0.99 & $99 \pm 0.5$ \\
\hline & & 50 & 49.5 & $99 \pm 1.0$ \\
\hline \multirow[t]{2}{*}{ B } & As in $\mathrm{A}+\mathrm{Mn}^{7+}(50)+\mathrm{As}^{3+}(50)+\mathrm{Ti}^{4+}(50)+\mathrm{Fe}^{3+}(50)+\mathrm{Se}^{4+}(50)+\mathrm{Hg}^{2+}(50)$ & 1.0 & 1.0 & $100 \pm 0.0$ \\
\hline & & 50 & 49.8 & $99.6 \pm 1.0$ \\
\hline \multirow[t]{2}{*}{$\mathrm{C}$} & As in $B+\mathrm{Pb}^{2+}(50)+\mathrm{W}^{6+}(50)+\mathrm{Cd}(50)+\mathrm{Zn}(50)+\mathrm{Na}(50)$ & 1.0 & 0.98 & $98 \pm 0.6$ \\
\hline & & 50 & 49.5 & $99 \pm 1.5$ \\
\hline \multirow[t]{2}{*}{$\mathrm{D}$} & As in $C+M g(50)+\mathrm{Ti}^{2+}(50)+\mathrm{Ag}(50)+\mathrm{Cu}(50)+\mathrm{Li}(50)$ & 1.0 & 1.0 & $100 \pm 0.0$ \\
\hline & & 50 & 49.96 & $99.9 \pm 1.3$ \\
\hline \multirow[t]{2}{*}{ E } & As in $\mathrm{D}+\mathrm{K}(50)+\mathrm{Co}^{2+}(50)+\mathrm{Bi}^{3+}(50)+\mathrm{Ca}(50)+\mathrm{Al}(50)$ & 1.0 & 0.99 & $99 \pm 1.5$ \\
\hline & & 50 & 49.7 & $99.4 \pm 1.8$ \\
\hline \multirow[t]{2}{*}{$\mathrm{F}$} & As in $\mathrm{E}+\mathrm{Sn}^{2+}(50)+\mathrm{Ba}(50)+\mathrm{Ce}^{3+}(50)+\mathrm{Sb}^{3+}(50)+\mathrm{Te}^{4+}(50)$ & 1.0 & 0.98 & $98 \pm 1.6$ \\
\hline & & 50 & 49.93 & $99.8 \pm 1.8$ \\
\hline
\end{tabular}

a Average of five analyses of each sample.

b The measure of precision is the standard deviation (SD).

Table 5. Determination of molybdenum in some certified reference materials

\begin{tabular}{|c|c|c|c|c|}
\hline \multirow[t]{2}{*}{ Sample } & \multirow{2}{*}{$\begin{array}{l}\text { Certified reference materials } \\
\text { (Composition, \%) }\end{array}$} & \multicolumn{3}{|l|}{ Molybdenum (\%) } \\
\hline & & In C.R.M. Sample & Found $(n=5)^{a}$ & RSD $^{\mathbf{b}}$ \\
\hline 1 & BAS-CRM 64b: High-speed steels (Cr, Mo, V, and Tc) & 4.95 & $4.92 \pm 0.05$ & 1.5 \\
\hline 2 & BAS-10g: High Speed brass ( $\mathrm{Cu}, \mathrm{Fe}, \mathrm{Pb}, \mathrm{Ni}, \mathrm{Sn}, \mathrm{Al}, \mathrm{Mo}, \mathrm{Zn}$, and $\mathrm{Mn}$ ) & 0.15 & $0.165 \pm 0.08$ & 1.8 \\
\hline 3 & BCS-CRM 200/2: High-speed tool steel (Mo, W, Mn, C, Si, S, O, V, Cr and Ni) & 4.92 & $4.91 \pm 0.8$ & 2.0 \\
\hline 4 & GSBH-40101-96: $\mathrm{Cr}_{12} \mathrm{MoV}$ : Dies steel (Cr, Mo, V, Ni, Cu, Co) & 1.00 & $0.98 \pm 0.05$ & 1.9 \\
\hline 5 & YSBC 1013-1-95; $\mathrm{Cr}_{17} \mathrm{MoVCo}$ : High tensile steels (C, $\mathrm{Cr}, \mathrm{Mo}, \mathrm{V}, \mathrm{Si}, \mathrm{Mn}$ and $\mathrm{Co}$ ) & 0.52 & $0.508 \pm 0.06$ & 2.0 \\
\hline 6 & NASS-1: Sea Water $\mathrm{f}$ & $11.5 \pm 1.8^{\mathrm{c}}$ & $11.03 \pm 1.5$ & 2.5 \\
\hline 7 & SWRS-1: River Water ${ }^{\mathrm{f}}$ & $0.78 \pm 0.04^{\mathrm{c}}$ & $0.77 \pm 0.5$ & 1.5 \\
\hline 8 & NIST ${ }^{\circledR S R M}{ }^{\circledR 1577 c: ~ B o v i n e ~ l i v e r ~}{ }^{f}$ & $3.3 \mathrm{~d}$ & $3.2 \pm 0.5$ & 2.0 \\
\hline 9 & ERM-BB001(EVISA): Human hairs e & $3.24 \pm 0.24 \mathrm{e}$ & $3.22 \pm 0.8$ & 2.5 \\
\hline
\end{tabular}

a The measure of precision is the standard deviation (SD)

b The measure of precision is the relative standard deviation (RSD).

c Values in $\mu \mathrm{g} / \mathrm{L}$

d Values in $\mathrm{mg} / \mathrm{kg}$

e Values in $\mu \mathrm{g} / \mathrm{kg}$.

f The CRMs were obtained from National Research Council, Govt. of Canada.

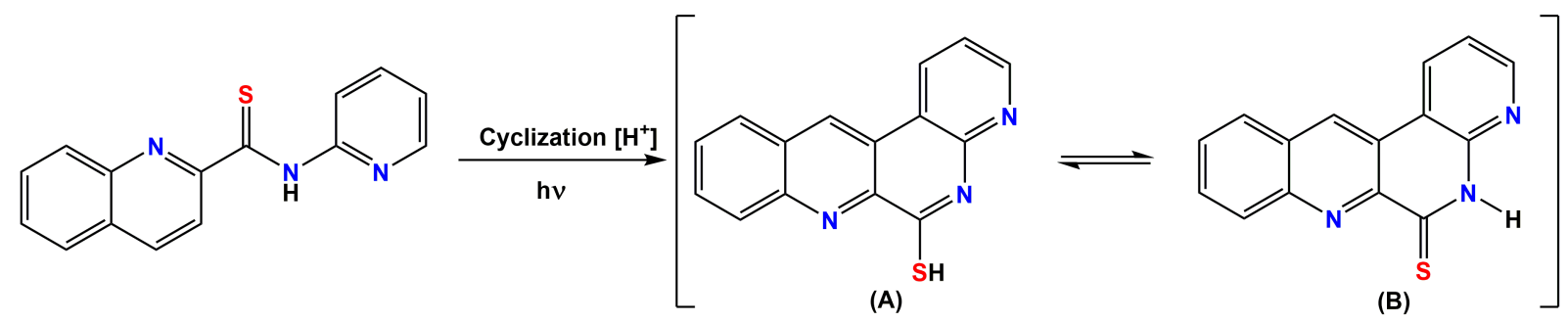

Scheme 2. Mechanism of oxidative cyclization reaction of $N$-(pyridin-2-yl)-quinoline-2-carbothioamide (PQTA).

The average percentage recovery obtained by addition of molybdenum (VI) spike to some environmental water samples was quantitative, as shown in Table 6 . The results of biological analyses by the spectrofluorimetric method were in excellent agreement with those obtained by ICP-OES (Table 7). The results of soil analyses by the spectrofluorimetric method were in excellent agreement with those obtained by AAS (Table 8). The results of food and vegetable analyses by spectrofluorimetric method were also found to be in excellent agreement with those obtained by ICP-OES (Table 9). The results of speciation of molybdenum (V) and molybdenum (VI) in the mixtures were highly reproducible (Table 10). Hence, the precision and accuracy of the method were found to be excellent.

\subsubsection{Nature of the fluorescent species}

The nonfluorescent reagent, PQTA, produced the same spectral characteristics with excitation and emission wavelengths almost invariably around 300 and $377 \mathrm{~nm}$, with molybdenum (VI), manganese (VII), chromium (VI), selenium (IV) and with persulphate, hydrogen peroxide, and tri-iodide in acidic media. This indicates that the fluorescence species is an oxidized product of the reagent itself and not a chelate. Similar oxidative fluorescent reactions have been utilized previously
$[56,63,65]$. The PQTA reagent produced here has so many potential reaction sites that the structure of the oxidized fluorescent species is difficult to predict. Given that ring closure can lead to intense fluorescent in some circumstances, it seems likely that photo-oxidative cyclization occurs, leading to the formation of structure (A) in resonance with structure (B) (Scheme 2).

\section{Applications}

The procedure was applied for the determination of trace amounts of molybdenum in some synthetic mixtures of various compositions (Table 4) and in a number of real samples, e.g., several Certified Reference Materials (CRMs) (Table 5). The method was also extended to the determination of molybdenum in a number of environmental, biological, soil, food, vegetable, and fruit samples. In view of the unknown composition of environmental water samples, the same equivalent portions of each such sample were analyzed for molybdenum content; the recoveries in both the "spiked" (added to the samples before mineralization or dissolution) and the "unpicked" samples are in excellent agreement (Table 6). The results of biological analyses by spectrofluorimetric method were found to be in excellent agreement with those obtained by ICP-OES (Table 7). 
Table 6. Determination of molybdenum in some environmental water samples.

\begin{tabular}{|c|c|c|c|c|c|}
\hline \multirow[t]{2}{*}{ Sample } & . & \multicolumn{2}{|c|}{ Molybdenum $(\mu \mathrm{g} / \mathrm{L})$} & \multirow[t]{2}{*}{ Recovery \pm s (\%) } & \multirow[t]{2}{*}{$s_{\mathrm{r}}(\%)^{\mathrm{b}}$} \\
\hline & & Added & Found $(n=5)^{a}$ & & \\
\hline \multirow{3}{*}{\multicolumn{2}{|c|}{ Tap water }} & 0 & 55.0 & & \\
\hline & & 10 & 65.0 & $100.0 \pm 0.0$ & 0.00 \\
\hline & & 50 & 108.0 & $103.0 \pm 0.5$ & 0.25 \\
\hline \multirow{3}{*}{\multicolumn{2}{|c|}{ Well water }} & 0 & 35.0 & & \\
\hline & & 10 & 45.0 & $100 \pm 0.0$ & 0.00 \\
\hline & & 50 & 85.0 & $100 \pm 0.0$ & 0.00 \\
\hline \multirow[t]{12}{*}{ River water } & Karnaphully & 0 & 75.0 & & \\
\hline & (upper) & 10 & 88.0 & $104.0 \pm 06$ & 0.35 \\
\hline & & 50 & 125.0 & $100.0 \pm 0.0$ & 0.00 \\
\hline & Karnaphully & 0 & 80.5 & & \\
\hline & (lower) & 10 & 90.0 & $99.5 \pm 0.5$ & 0.21 \\
\hline & & 50 & 135.0 & $103.0 \pm 0.8$ & 0.39 \\
\hline & Halda & 0 & 45.0 & & \\
\hline & (upper) & 10 & 55.0 & $100.0 \pm 0.00$ & 0.00 \\
\hline & & 50 & 98.0 & $103.0 \pm 0.6$ & 0.29 \\
\hline & Halda & 0 & 53.0 & & \\
\hline & (lower) & 10 & 65.0 & $103.0 \pm 0.8$ & 0.36 \\
\hline & & 50 & 105.0 & $102.0 \pm 0.5$ & 0.33 \\
\hline \multirow[t]{6}{*}{ Sea water } & Bay of Bengal & 0 & 25.0 & & \\
\hline & (upper) & 10 & 35.0 & $100.0 \pm 0.0$ & 0.00 \\
\hline & & 50 & 80.0 & $106.0 \pm 1.0$ & 0.45 \\
\hline & Bay of Bengal & 0 & 35.0 & & \\
\hline & (lower) & 10 & 45.0 & $100.0 \pm 0.0$ & 0.00 \\
\hline & & 50 & 90.0 & $105.8 \pm 1.0$ & 0.38 \\
\hline \multirow[t]{15}{*}{ Drain water } & Triple super phosphate Complex $^{c}$ & 0 & 130.0 & & \\
\hline & & 100 & 235.0 & $102.0 \pm 0.8$ & 0.18 \\
\hline & & 500 & 630.0 & $100.2 \pm 0.0$ & 0.00 \\
\hline & PHP d & 0 & 160.0 & & \\
\hline & & 100 & 260.0 & $100.0 \pm 0.0$ & 0.00 \\
\hline & & 500 & 665.0 & $100.7 \pm 0.5$ & 0.25 \\
\hline & BSRM e & 0 & 245.0 & & \\
\hline & & 100 & 350.0 & $101.0 \pm 0.8$ & 0.29 \\
\hline & & 500 & 750.0 & $100.6 \pm 1.0$ & 0.35 \\
\hline & KPM Water $\mathrm{f}$ & 0 & 188.0 & & \\
\hline & & 100 & 288.0 & $100.0 \pm 0.8$ & 0.00 \\
\hline & & 500 & 690.0 & $100.2 \pm 0.5$ & 0.42 \\
\hline & Berger paints $\mathrm{g}$ & 0 & 270.0 & & \\
\hline & & 100 & 370.0 & $100.0 \pm 0.0$ & 0.00 \\
\hline & & 500 & 775.0 & $100.6 \pm 1.2$ & 0.55 \\
\hline
\end{tabular}

average of five replicate determinations of each sample.

b The measure precision is the relative standard deviation $\left(\mathrm{s}_{\mathrm{r}}\right)$.

${ }^{c}$ Triple super phosphate Complex, Patenga, Chittagong.

d PHP Group of Glass Factory, Chittagong.

e Bangladesh Steel Re-rolling Mills Ltd. (BSRM), Baizid-Bosthami, Chittagong.

${ }_{\mathrm{f}}$ Karnaphully Paper Mills (KPM), Chandraghona, Chittagong.

g Berger Paints Bangladesh Limited, Kalurghat, Chittagong.

Table 7. Determination of molybdenum in some human fluids and hair samples.

\begin{tabular}{|c|c|c|c|c|c|c|}
\hline \multirow[t]{3}{*}{ Serial no } & \multirow[t]{3}{*}{ Sample source a } & \multirow[t]{3}{*}{ Sample } & \multicolumn{4}{|c|}{ Molybdenum $(\mu \mathrm{g} / \mathrm{L})$} \\
\hline & & & \multicolumn{2}{|c|}{ ICP-OES (n = 5) } & \multicolumn{2}{|c|}{ Proposed method $(n=5)$} \\
\hline & & & Found & RSD (\%) ${ }^{b}$ & Found & RSD (\%) \\
\hline \multirow[t]{2}{*}{1} & Cardiovascular patient & Blood & 115.0 & 1.8 & 118.5 & 2.0 \\
\hline & (Female) & Urine & 30.5 & 1.3 & 31.8 & 1.5 \\
\hline \multirow[t]{2}{*}{2} & Liver cirrhosis patient & Blood & 95.0 & 1.5 & 96.5 & 1.8 \\
\hline & (Male) & Urine & 24.5 & 1.0 & 25.6 & 1.2 \\
\hline \multirow[t]{2}{*}{3} & Lung cancer patient & Blood & 175.0 & 2.0 & 178.5 & 2.0 \\
\hline & (Male) & Urine & 45.5 & 1.5 & 48.0 & 1.6 \\
\hline \multirow[t]{2}{*}{4} & Kidney damage patient & Blood & 155.5 & 1.8 & 158.0 & 2.0 \\
\hline & (Female) & Urine & 40.8 & 1.3 & 42.0 & 1.5 \\
\hline \multirow[t]{2}{*}{5} & Skin disease patient & Blood & 168.5 & 2.0 & 170.8 & 2.2 \\
\hline & (Female) & Urine & 43.8 & 1.5 & 45.5 & 1.6 \\
\hline \multirow[t]{2}{*}{6} & Manic disease patient & Blood & 165.5 & 2.0 & 168.5 & 2.0 \\
\hline & (Male) & Urine & 42.6 & 1.5 & 44.5 & 1.8 \\
\hline \multirow[t]{2}{*}{7} & Diabetic patient & Blood & 45.8 & 1.5 & 48.6 & 1.5 \\
\hline & (Male) & Urine & 11.5 & 1.0 & 12.5 & 1.2 \\
\hline \multirow[t]{2}{*}{8} & Normal nonsmoker & Blood & 11.5 & 1.5 & 12.0 & 1.3 \\
\hline & (Female) & Urine & 3.5 & 1.0 & 3.8 & 1.0 \\
\hline 10 & Lactating mother & Human milk & 10.5 & 1.5 & 10.8 & 1.5 \\
\hline 11 & Normal nonsmoker (Male) & Human hair & $0.35 \mathrm{c}$ & 1.0 & 0.36 & 1.0 \\
\hline
\end{tabular}

a Samples were collected from Chittagong Medical College Hospital.

$\mathrm{b}$ The measures of precision is the relative standard deviation (RSD).

c Values in $\mathrm{mg} / \mathrm{g}$.

The results of soil analyses by the spectrofluorimetric method were found to be in excellent agreement with those obtained by AAS (Table 8). The results of food analyses by spectrofluorimetric method were also found to be in excellent agreement with those obtained by ICP-OES (Table 9). The results of speciation of molybdenum (V) and molybdenum (VI) in the mixtures were highly reproducible (Table 10). 
Table 8. Determination of molybdenum in some soil samples.

\begin{tabular}{|c|c|c|c|c|c|}
\hline \multirow[t]{3}{*}{ Serial no } & \multirow[t]{3}{*}{ Sample source } & \multicolumn{4}{|c|}{ Molybdenum (mg/kg) (n = 5) } \\
\hline & & \multicolumn{2}{|c|}{ AAS (n=5) } & \multicolumn{2}{|c|}{ Proposed method ( $n=5)$} \\
\hline & & Found a & RSD (\%) ${ }^{b}$ & Found & RSD (\%) ${ }^{b}$ \\
\hline 1 & Agricultural Soil (Chittagong University) & 1.70 & 1.0 & 1.72 & 1.0 \\
\hline 2 & Glass Industrial Soil (PHP glass) & 1.96 & 1.4 & 1.98 & 1.5 \\
\hline 3 & Steel Industrial Soil (BSRM, Chittagong, Bangladesh) & 2.33 & 1.8 & 2.35 & 2.0 \\
\hline 4 & Paint Industrial Soil (Berger paint) & 2.38 & 2.5 & 2.41 & 2.0 \\
\hline 5 & Paint Industrial Soil (Elite Paints) & 2.28 & 1.8 & 2.31 & 1.5 \\
\hline 6 & Industrial Soil (Eastern Cables Ltd) & 1.98 & 2.0 & 2.05 & 1.8 \\
\hline 7 & Fertilizer Industrial Soil (T.S.P. Complex Ltd. Chattogram) & 2.08 & 1.5 & 2.15 & 1.6 \\
\hline 8 & Marine Soil (Sediments) & 1.18 & 1.0 & 1.20 & 1.0 \\
\hline 9 & Traffic Soil (Kadamtoli Bus Terminal Chattogram) & 1.36 & 1.6 & 1.38 & 1.5 \\
\hline 10 & Pharmaceutical Soil (Glaxo Smith Kline) & 1.85 & 2.0 & 1.88 & 1.6 \\
\hline
\end{tabular}
Pharmaceutical Soil (Glaxo Smith Kline)

Average of five replicate analysis of each sample.

$\mathrm{b}$ The measure of precision is the relative standard deviation (RSD).

c Composition of the soil samples: $\mathrm{C}, \mathrm{N}, \mathrm{P}, \mathrm{K}, \mathrm{Na}, \mathrm{Ca}, \mathrm{Mg}, \mathrm{Fe}, \mathrm{Pb}, \mathrm{Cu}, \mathrm{Zn}, \mathrm{Mn}, \mathrm{Mo}, \mathrm{Co}, \mathrm{NO}_{3}, \mathrm{NO}_{2}, \mathrm{SO}_{4}$, etc.

Table 9. Determination of molybdenum in some food, fruit, and vegetable samples.

\begin{tabular}{|c|c|c|c|c|c|c|}
\hline \multirow[t]{3}{*}{ Serial no } & \multirow[t]{3}{*}{ Sample } & \multicolumn{4}{|c|}{ Molybdenum $(\mu \mathrm{g} / \mathrm{kg})$ Found $\pm s(n=5){ }^{a}$} & \multirow{3}{*}{ Sample source } \\
\hline & & \multicolumn{2}{|c|}{ ICP-OES (n = 5) } & \multicolumn{2}{|c|}{ Proposed method (n=5) } & \\
\hline & & Found & RSD (\%) ${ }^{b}$ & Found & RSD (\%) b & \\
\hline 1 & Carrot (Daucus carota) & 66.8 & 1.0 & 68.5 & 1.2 & Local Market, Chittagong \\
\hline 2 & Rice (Oryza sativa) & 405.0 & 2.0 & 408.0 & 2.0 & Local Market, Chittagong \\
\hline 3 & Wheat (Trictiumaestivum) & 388.0 & 2.0 & 391.0 & 2.1 & Local Market, Chittagong \\
\hline 4 & Tomato (Lycopersicon esculentum) & 145.0 & 1.0 & 48.5 & 1.2 & Local Market, Chittagong \\
\hline 5 & Potato (Solanum tuberosum) & 175.0 & 1.3 & 78.5 & 1.5 & Local Market, Chittagong \\
\hline 6 & Corn (Zea mays) & 147.0 & 1.5 & 150.1 & 1.8 & Local Market, Chittagong \\
\hline 7 & Spinach (Spinacia oleracea) & 135.0 & 1.2 & 138.5 & 1.6 & Local Market, Chittagong \\
\hline 8 & Radish (Raphanus sativus) & 48.5 & 1.0 & 51.0 & 1.5 & Local Market, Chittagong \\
\hline 9 & Cabbage (Brassica oleracea) & 75.0 & 1.2 & 78.5 & 1.3 & Local Market, Chittagong \\
\hline 10 & Arum (Arum discorides) & 260.0 & 2.5 & 263.5 & 2.5 & Local Market, Chittagong \\
\hline 11 & Garlic (Allium sativum) & 190.0 & 2.3 & 192.5 & 2.4 & Local Market, Chittagong \\
\hline 12 & Lentils (Lens culinaris) & 148.5 & 1.5 & 150.8 & 1.5 & Local Market, Chittagong \\
\hline 13 & Eggs (Gallus domesticus) & 77.5 & 1.0 & 80.8 & 1.6 & Local Market, Chittagong \\
\hline
\end{tabular}

average of five replicate analyses of each sample.

$\mathrm{b}$ The measure of precision is the relative standard deviation (RSD).

\subsection{Determination of molybdenum in synthetic mixtures}

The procedure was applied to determine trace amounts of molybdenum (VI) in some synthetic mixtures with good recovery being achieved. The result indicates that the proposed method is suitable and can be successfully applied for the determination of Mo (VI). Several synthetic mixtures of varying compositions containing molybdenum (VI) and diverse ions of known concentrations were determined by the present method using EDTA as the masking agent. The results were found to be highly reproducible as shown in Table 4 . Accurate recoveries were achieved in all solutions in the range $99.6 \pm 1.5$ to $99.9 \pm 0.6 \%$. The reliability of our molybdenum-PQTA oxidation procedure was approved by quantitative recovery of molybdenum (VI) spiked in several synthetic mixtures containing molybdenum (VI) and diverse ions. This method has high precision and accuracy ( $\mathrm{s}= \pm 0.01$ for $0.5 \mu \mathrm{g} / \mathrm{L}$ ).

\subsection{Determination of molybdenum in some certified reference materials}

A $0.1 \mathrm{~g}$ amount of an alloy or steel sample containing 0.15 $4.95 \%$ of molybdenum was weighed accurately and placed in a $50 \mathrm{~mL}$ Erlenmeyer flask in the presence of excess oxidizing agent to oxidize molybdenum (V) to molybdenum (VI) following a method recommended by Mitra [66]. To it, $10 \mathrm{~mL}$ of $20 \%(w: v)$ sulfuric acid was added and while carefully covered with a watch glass until the brisk reaction subsided. The solution was heated and simmered gently after the addition of $10 \mathrm{~mL}$ of concentrated $\mathrm{HNO}_{3}$ until all residual carbides were decomposed. Then a further2 $\mathrm{mL}$ of $1+1 \mathrm{H}_{2} \mathrm{SO}_{4}$ and $2 \mathrm{~mL} 2 \%$ $(w: v)$ freshly prepared ammonium persulphate were added and the solution was evaporated carefully to dense white fumes of sulphur trioxide, then cooled to room temperature $\left(25 \pm 5^{\circ} \mathrm{C}\right)$. After suitable dilution with deionized water, the contents of the Erlenmeyer flask were warmed to dissolve the soluble salts. The solution was then cooled and neutralized with dilute
$\mathrm{NH}_{4} \mathrm{OH}$ solution in the presence of $1-2 \mathrm{~mL}$ of $0.01 \%(w: v)$ EDTA solution. The resulting solution was filtered if necessary, through a Whatman No. 40 filter paper into a $100 \mathrm{~mL}$ calibrated flask. The residue (silica and tungstic acid) was washed with a small volume of hot $1+99 \mathrm{H}_{2} \mathrm{SO}_{4}$, followed by water; the volume was made up to the mark with deionized water.

A suitable aliquot $(1-2 \mathrm{~mL})$ of the above-mentioned solution was taken into a $10 \mathrm{~mL}$ calibrated flask and the molybdenum (VI) content was determined; as described under the procedure using tartrate or EDTA as the masking agent. The proposed procedure for the spectrofluorimetric determination of molybdenum was applied to the analysis of sea water (NASS-1), river water (SWRS-1), human hair: ERM-BB001(EVISA) and Bovine liver (NIST@SRM-1577c). The CRMs were obtained from the National Research Council, Govt. of Canada, using tartrate or EDTA as masking agents, following a method recommended by Sun et al. [67]. Based on five replicate analyses, the average molybdenum concentration determined by the spectrofluorimetric method was in excellent agreement with the certified values. The results are given in Table 4 .

\subsection{Determination of molybdenum in environmental water samples}

Each filtered (with Whatman No. 40) environmental sample $(25 \mathrm{~mL})$ contained in a $50 \mathrm{~mL}$ Pyrex beaker were added $1 \mathrm{~mL}$ of concentrated $\mathrm{H}_{2} \mathrm{SO}_{4}$ and $2 \mathrm{~mL}$ of concentrated $\mathrm{HNO}_{3}$ in the presence of freshly prepared excess ammonium persulphate solution in a fume cupboard to oxidize molybdenum (V) to molybdenum (VI) and the mixture was heated on a hot plate until white fumes of sulfur trioxide, following a method recommended by Greenberg et al. [68]. The solution was cooled and neutralized with dilute $\mathrm{NH}_{4} \mathrm{OH}$ solution in the presence of $1-2 \mathrm{~mL}$ of $0.01 \%$ ( $w: v$ ) EDTA solution. The resulting solution was then filtered through a Whatman No. 40 filter paper and quantitatively transferred into a $25 \mathrm{~mL}$ calibrated flask and made up to the mark with de-ionized water. 
Table 10. Determination of molybdenum (V) and molybdenum (VI) speciation in mixtures.

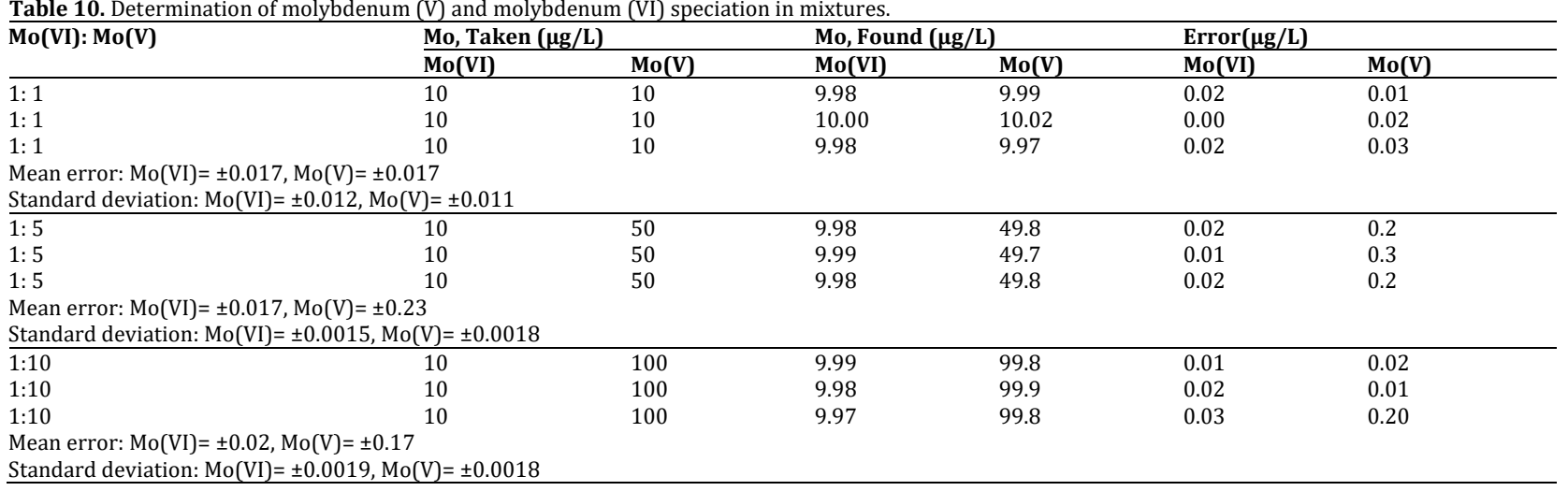

An aliquot (1-2 $\mathrm{mL}$ ) of this water sample was pipetted into a $10 \mathrm{~mL}$ calibrated flask and the molybdenum content was determined as described under the general procedure using tartrate or EDTA as the masking agent. To test the validity of our method, we have analyzed different types of portable and polluted waters in spike and unpick conditions. The reliability of our spectrofluorimetric method was tested by recovery studies. The average percentage recovery obtained for the addition of a molybdenum (VI) spike to some environmental water samples was quantitative. The results of analyses of environmental water samples from various sources for molybdenum are shown in Table 6. Most spectrofluorimetric methods for the determination of molybdenum in natural and sea water require preconcentration or standard addition of molybdenum [68]. The concentration of molybdenum in natural and sea water is a few $\mu \mathrm{g} / \mathrm{L}$ in Japan [69]. The mean concentration of molybdenum found in US drinking waters is 6 $\mu \mathrm{g} / \mathrm{L}[70]$

\subsection{Determination of molybdenum in biological samples}

Human blood or milk (2-3 mL) or urine (10-20 mL) or hair (3-5 g) sample was taken into a $100 \mathrm{~mL}$ micro-Kjeldahl flask. A glass bead and $10 \mathrm{~mL}$ of concentrated nitric acid were added, and the flask was placed on the digester under gentle heating. The sample was digested in the presence of an excess freshly prepared ammonium persulphate solution ( $2 \mathrm{~mL}$ of $2 \% \mathrm{w}: \mathrm{v}$ ) to oxidize molybdenum (V) to molybdenum (VI) according to the method recommended by Stahr [71]. As the heating process continued, $1 \mathrm{~mL}$ of $\mathrm{H}_{2} \mathrm{SO}_{4}$ is added and heated for about 0.5 hour to dense white fumes of sulphur trioxide. When the initial brisk reaction was completed, the solution was removed and cooled at room temperature and neutralized with dilute $\mathrm{NH}_{4} \mathrm{OH}$ solution in the presence of $1-2 \mathrm{~mL}$ of $0.01 \%(w: v)$ EDTA solution. The resulting solution was then filtered through a Whatman No. 40 filter paper and quantitatively transferred into a $25 \mathrm{~mL}$ calibrated flask and made up to the mark with deionized water.

A suitable aliquot (1-2 mL) of the final solution was pipetted out into a $10 \mathrm{~mL}$ calibrated flask and the molybdenum content was determined as described under the general procedure using EDTA or tartrate as the masking agent. The results of biological analyses by the spectrofluorimetric method were found to be in excellent agreement with those obtained by ICPOES. The results are shown in Table 7 . The abnormally high values for gastrointestinal disturbance and cardiovascular patients are probably due to the involvement of high molybdenum concentrations with As and $\mathrm{Zn}$. The occurrence of such high molybdenum contents is also reported in gastrointestinal disturbances and cardiovascular patients from some developed countries [59].

\subsection{Determination of molybdenum in some surface soil samples}

An air-dried homogenized soil sample (10 g) was accurately weighed and placed in a $100 \mathrm{~mL}$ micro-Kjeldahl flask. The sample was digested in the presence of an excess oxidizing agent ( $2 \mathrm{~mL}$ of $2 \%$ freshly prepared ammonium persulfate solution) to oxidize molybdenum (V) to molybdenum (VI) following the method recommended by Jackson [72]. As the heating process continued, $1 \mathrm{~mL}$ of $\mathrm{H}_{2} \mathrm{SO}_{4}$ is added and heated for about 5 minutes to dense white fumes of sulphur trioxide. The solution was then cooled at room temperature and neutralized with dilute $\mathrm{NH}_{4} \mathrm{OH}$ solution in the presence of 1-2 $\mathrm{mL}$ of $0.01 \%(w: v)$ EDTA solution. The content of the flask was then filtered through a Whatman No. 40 filter paper and quantitatively transferred into a $25 \mathrm{~mL}$ calibrated flask and made up to the mark with deionized water. A suitable aliquot (1-2 $\mathrm{mL})$ of the final solution was pipetted out into a $10 \mathrm{~mL}$ calibrated flask and the molybdenum content was determined as described under the general procedure using tartrate or EDTA as the masking agent. The molybdenum content was then determined by the above procedure and quantified from a calibration graph prepared concurrently. The results of soil analyses by spectrofluorimetric method were also found to be in excellent agreement with those obtained by AAS. The average value of molybdenum in the Chittagong region surface soil was found to be $1.9 \mathrm{mg} / \mathrm{kg}$. The results are shown in Table 8.

\subsection{Determination of molybdenum in some vegetable, food, and fruit samples}

The vegetable and fruit samples collected prior to determination were pretreated in the following way: Edible portion of samples was first washed clean with tap water followed by rewashing with de-ionized water. After removing deionized water from the surface of vegetables and fruits, the samples were cut into small pieces and dried at $65^{\circ} \mathrm{C}$ in oven. An air-dried vegetable and fruit samples $(10 \mathrm{~g})$ were ground in a mortar and taken in a $100 \mathrm{~mL}$ micro-Kjeldahl flask in the presence of excess oxidizing agent and digested following the method recommended by Stahr [71] and $10 \mathrm{~mL}$ of concentrated nitric acid were added and the flask was placed on the digester under gentle heating. When the initial brisk reaction was over, the solution was removed and cooled at room temperature. 1 $\mathrm{mL}$ volume of concentrated sulfuric acid was added carefully, followed by the addition of $2 \mathrm{~mL}$ of concentrated $\mathrm{HF}$, and the heating was continued for at least $1 / 2 \mathrm{~h}$. and then cooled. In the resulting solution, $2 \mathrm{~mL}$ of $2 \%(w: v)$ of freshly prepared ammonium persulfate is added. The mixture of each foodstuff was heated below the boiling point for 5-10 min to oxidize molybdenum (V) to molybdenum (VI). The solutions were then cooled and neutralized with dilute $\mathrm{NH}_{4} \mathrm{OH}$ in the presence of 1- 
$2 \mathrm{~mL}$ of $0.01 \%(w: v)$ EDTA solution. The resulting solution was filtered through a Whatman No. 40 filter paper and quantitatively transferred into a $25 \mathrm{~mL}$ calibrated flask and mixed well and made up to the mark with deionized water.

The food samples used were rice, wheat, and corn and these were used under dry conditions. Each sample was first ground in a mortar. Corn and fruit samples $(2 \mathrm{~g})$ or rice and wheat samples $(1 \mathrm{~g})$ were weighed accurately and placed in a porcelain crucible and charred in an electric furnace; the sample was ashen at $555^{\circ} \mathrm{C}$ in a muffle furnace in the presence of excess oxidizing agent following a method recommended by Mitra [66]. To it, $2.0 \mathrm{~mL}$ of $\mathrm{HCl}$ and $10 \mathrm{~mL}$ of water were added to the ash. The mixture of each foodstuff was heated with $2 \mathrm{~mL}$ of $2 \%(w: v)$ freshly prepared ammonium persulphate was added below the boiling point for 5-10 min to complete the oxidation from Mo (V) to Mo (VI). The solutions were cooled and neutralized with dilute $\mathrm{NH}_{4} \mathrm{OH}$ in the presence of 1-2 $\mathrm{mL}$ of $0.01 \%(w: v)$ EDTA solution and filtered. The resulting solution was quantitatively transferred into a $25 \mathrm{~mL}$ calibrated flask and mixed well and made up to the mark with deionized water.

A suitable aliquot $(1-2 \mathrm{~mL})$ of the final digested solution was pipetted into a $10 \mathrm{~mL}$ calibrated flask and the molybdenum content was determined as described under the general procedure using tartrate as the masking agent. A high value of molybdenum in rice is probably due to the involvement of high molybdenum concentration in soil [27]. The results of food and vegetable analyses by spectrofluorimetric method were also found to be in excellent agreement with those obtained by ICPOES. The results are shown in Table 9.

\subsection{Determination of molybdenum (V) and molybdenum (VI)speciation in mixtures}

Suitable aliquots $(1-2 \mathrm{~mL})$ of molybdenum $(\mathrm{V}+\mathrm{VI})$ mixtures (preferably 1:1, 1:5, 1:10) were taken in a $250 \mathrm{~mL}$ Pyrex conical flask. A few drops (3-5 drops) of $4 \mathrm{M} \mathrm{H}_{2} \mathrm{SO}_{4}$, and 5-10 mL of $2 \%$ $(w: v)$ freshly prepared ammonium persulphate were added to oxidize pentavalentmolybdenum and the mixture was heated gently with further addition of $10 \mathrm{~mL}$ water, if necessary, for 5 minutes to drive off the excess persulphate, then the mixture was cooled to room temperature $\left(25 \pm 5{ }^{\circ} \mathrm{C}\right)$. The reaction mixture was then cooled and neutralized with dilute $\mathrm{NH}_{4} \mathrm{OH}$ in the presence of $3-5 \mathrm{~mL}$ of $0.01 \%(w: v)$ EDTA solution. The solution was transferred quantitatively into a $25 \mathrm{~mL}$ volumetric flask and $2.5 \mathrm{~mL}$ of $3.77 \times 10^{-3} \mathrm{M}$ PQTA reagent solution was added, followed by the addition of $2.5 \mathrm{~mL}$ of $0.025 \mathrm{M} \mathrm{H}_{2} \mathrm{SO}_{4}$. It was made up to the mark with de-ionized water. The fluorescence intensity was measured then being cooled at room temperature $\left(25 \pm 5^{\circ} \mathrm{C}\right)$, at $377 \mathrm{~nm}$ when excited at $300 \mathrm{~nm}$, against a reagent blank. The total molybdenum content was calculated with the help of a calibration graph prepared concurrently.

An equal aliquot (1-2 $\mathrm{mL}$ ) of the molybdenum(V+VI) mixture was taken into a $250 \mathrm{~mL}$ Pyrex conical flask. The solution was neutralized with dilute $\mathrm{NH}_{4} \mathrm{OH}$ in the presence of 3-5 mL of $0.01 \%(w: v)$ EDTA solution. After the content of the beaker was transferred quantitatively into a $25 \mathrm{~mL}$ volumetric flask, $2.5 \mathrm{~mL}$ of $3.77 \times 10^{-3} \mathrm{M}$ PQTA reagent solution was added, followed by the addition of $2.5 \mathrm{~mL}$ of $0.05 \mathrm{M} \mathrm{H}_{2} \mathrm{SO}_{4}$. It was made up to the mark with deionized water. After $5 \mathrm{~min}$, the fluorescence intensity was measured following the general procedure at $377 \mathrm{~nm}$ when excited at $300 \mathrm{~nm}$ against a reagent blank, as before. The molybdenum concentration was calculated in $\mu \mathrm{g} / \mathrm{L}$ or ng/L with the aid of a calibration graph. This gives a measure of molybdenum (VI) originally present in the mixture. This value was subtracted from that of the total molybdenum to determine the molybdenum (V) present in the mixture. The results of the assessment of speciation of Mo (VI) and Mo (V) were found to be highly reproducible. The occurrence of such reproducible results is also reported for different oxidation states of molybdenum [73]. The results of a set of determination are given in Table 10.

\section{Conclusions}

A new simple, rapid, ultra-sensitive, highly selective, and inexpensive spectrofluorimetric method with the molybdenum-PQTA system was developed for the determination of molybdenum in some real, environmental, biological, food, vegetable and soil samples. Although many sophisticated techniques such as pulse polarography, HPLC, AAS, ICP-OES, and ICP-MS, are available for the determination of molybdenum at trace levels in numerous complex materials, factors such as the low cost of the instrument, easy handling, lack of requirement for consumables and almost no maintenance have caused spectrofluorimetry to remain a popular technique, particularly in laboratories of developing countries with limited budgets.

The sensitivity and precision in terms of relative standard deviation of the present method is very reliable for the determination of molybdenum in real samples down to $\mathrm{pg} / \mathrm{g}$ $\left(10^{-12} \mathrm{~g}\right)$ levels in aqueous medium at room temperature $(25 \pm 5$ ${ }^{\circ} \mathrm{C}$ ). It is a new method, needs neither heating nor extraction of organic phase, works satisfactorily, and could be an alternative method for the rapid determination of molybdenum in a wide variety of sample matrices and found superior to existing spectrofluorimetric methods reported in different literature [19-52].

\section{Acknowledgements}

We are thankful to the Authorities of Chittagong Medical College Hospital and Chittagong Treatment Hospital for supplying biological samples. We are also thankful to the Authorities of "Training Institute for Chemical Industries" (TICI), Polash, Norsindi, Dhaka, Bangladesh for analyzing water, biological, and food samples by Inductively Coupled PlasmaOptical Emission Spectrophotometer (ICP-OES).

\section{Disclosure statement DS}

Conflict of interest: The authors declare that they have no conflict of interest.

Author contributions: All authors contributed equally to this work.

Ethical approval: All ethical guidelines have been adhered.

Sample availability: Samples of the compounds are available from the authors

\section{ORCID}

Muhammad Jamaluddin Ahmed

(iD) https://orcid.org/0000-0002-3765-066X

Ayesha Afrin

(iD) https://orcid.org/0000-0002-4820-063X

Muhammad Emdadul Haque

(iD https://orcid.org/0000-0003-1207-7083

\section{References}

[1]. Hurliy, L. S.; Bratter, P.; Schramel, P. Trace Element Analytical Chemistry in Medicine and Biology, $6^{\text {th }}$ edition, John Wiley \& Sons, 1994.

[2]. Institute of Medicine, Molybdenum, In: Dietary Reference Intakes for Vitamin A, Vitamin K, Arsenic, Boron, Chromium, Copper, Iodine, Iron, Manganese, Molybdenum, Nickel, Silicon, Vanadium, and Zinc. Washington, DC: The National Academies Press, 2000.

[3]. Coughlan, M. P. J. Inherit. Metab. Dis. 1983, 6 (S1), 70-77.

[4]. Burgmayer, S. J. N.; Stiefel, E. I. J. Chem. Educ. 1985, 62 (11), 943-953.

[5]. Considine, S.; Glenn, D., Molybdenum, Van Nostrand's Encyclopedia of Chemistry. New York, Wiley-Interscience, 2005. 
[6]. Sebenik, R. F.; Burkin, A. R.; Dorfler, R. R.; Laferty, J. M.; Leichtfried, G.; Meyer-Grünow, H.; Mitchell, P. C. H.; Vukasovich, M. S.; Church, D. A.; Van Riper, G. G.; Gilliland, J. C.; Thielke, S. A. Molybdenum and Molybdenum Compounds. Ullmann's Encyclopedia of Industrial Chemistry, 2000.

[7]. Lal, S.; Patil, R. S. Environ. Monit. Assess. 2001, 68 (1), 37-50.

[8]. Shpak, A. P.; Kotrechko, S. O.; Mazilova, T. I.; Mikhailovskij, I. M. Sci. Technol. Adv. Mater. 2009, 10 (4), 045004.

[9]. Ahmed, M. J.; Haque, M. E. Anal. Sci. 2002, 18 (4), 433-439.

[10]. Sun, Y. Talanta 2000, 52 (3), 417-424.

[11]. Kalal, H. S.; Panahi, H. A.; Framarzi, N.; Moniri, E.; Naeemy, A.; Hoveidi, H.; Abhari, A. Int. J. Environ. Sci. Technol. 2011, 8 (3), 501-512.

[12]. Reid, H.; Bashammakh, A.; Goodall, P.; Landon, M.; Oconnor, C.; Sharp, B. Talanta 2007, 2008, 75 (1) 189-197.

[13]. Yu, J. C.; Chan, S. M.; Chen, Z. Anal. Bioanal. Chem. 2003, 376 (5), 728734

[14]. Gil, R. A.; Pasini-Cabello, S.; Takara, A.; Smichowski, P.; Olsina, R. A.; Martinez, L. D. Microchem. J. 2007, 86 (2), 156-160.

[15]. Burba, P.; Willmer, P. G. Z. Anal. Chem. 1986, 324 (3-4), 298-299.

[16]. Ohashi, H.; Uehara, N.; Shijo, Y. J. Chromatog. A 1991, 539 (1), 225-231.

[17]. Yigmatepe, E.; Yaman, M. Monatsh Chem. 2011, 142 (2), 131-136.

[18]. Sanchez, M. Talanta 1991, 38 (7), 747-752.

[19]. Jiang, C.; Wang, J.; He, F. Anal. Chim. Acta 2001, 439 (2), 307-313.

[20]. Capitan, F.; Sanchez-Palencia, G.; Navalon, A.; Fermin Capitan-Vallvey, L.; Luis Vilchez, J. Anal. Chim. Acta 1992, 259 (2), 345-353.

[21]. Pyrzynska, K. Anal. Chim. Acta 2007, 590 (1), 40-48.

[22]. Cruces Blanco, C.; Garcia Campana, A.; Ales Barrero, F.; Roman Ceba, M. Anal. Chim. Acta 1993, 283 (1), 213-223.

[23]. Bian, W. W. Appl. Mech. Mater. 2014, 556-562, 584-587.

[24]. Kawakubo, S.; Suzuki, H.; Iwatsuki, M. Anal. Sci. 1996, 12 (5), 767-771.

[25]. Vilchez, J. L.; Sanchez-Palencia, G.; Blanc, R.; Avidad, R.; Navalon, A. Anal. Lett. 1994, 27 (12), 2355-2368.

[26]. Salinas, F.; de la Pena, A. M.; Capitan-Vallvey, L. F.; Navalon, A. Analyst 1989, 114 (10), 1297-1301.

[27]. Haddad, P. R.; Alexander, P. W.; Smythe, L. E. Talanta 1975, 22 (1), 6169.

[28]. Jie, Z.; Sixuan, G.; Zaizheng, Z.; Bin, W.; Zhenghong, Z. Chinese J. Anal. Lab. 1998, 17 (1), 73-75.

[29]. Mori I.; Fujita Y.; Kamata Y.; Enoki T. Bunseki Kagaku 1978, 27 (5), 259-263.

[30]. Xie, Y.; Yan, X.; Tong, H.; Liu, S. Asian J. Chem. 2007, 19 (2), 1017-1022.

[31]. Campana, A. M. G.; Barrero, F. A.; Ceba, M. R.; Gutierrez, A. F. Analyst 1994, $119(8), 1903-1906$.

[32]. Blanco, C. Talanta 1995, 42 (8), 1037-1044

[33]. Chin, Y. W.; Chai, H. B.; Keller, W. J.; Kinghorn, A. D. J. Agric. Food Chem. 2008, 56 (17), 7759-7764.

[34]. Shaofei, S.; Ping, L.; Ful, Z. J. Hangzhou Normal Univ. Natural Sci. Edit. 2015, 2, 178-182.

[35]. Song, G, S.; Guo, Y.; Ren, H. Chinese J. Anal. Lab. 2005, 5, 44-47.

[36]. Tabaraki, R.; Abdi, O.; Yousefipour, S. J. Fluoresc. 2016, 27 (2), 651-

[37]. Pal, B.; Singh, K.; Dutta, K. Talanta 1992, 39 (8), 971-975.

[38]. Feng, G.; Mi, H.; Fei, Q.; Shan, H.; Wang, B.; Xu, H.; Li, G.; Chen, F.; Huan, Y. Spectrochim. Acta A 2016, 167, 122-126.

[39]. Kirkbright, G. F.; West, T. S.; Woodward, C. Talanta 1966, 13 (12), 1637-1644.

[40]. Guoquan, G.; Liufang, W.; Mingming, L. Chinese J. Anal. Chem. 1993, 21 (5), 563-565.

[41]. Wang, X.; Jiang, M.; Bai, Z.; Yan, F. Metallurg. Anal. (China) 1989, 9 (5), $27-29$.
[42]. Bao, S. Y.; Li, S. C.; Wang, G. H.; Hu, H. F. J. Hebei Univ. (Natural Sci. Ed.) 2001, 21 (1), 61-64.

[43]. Maosheng, G.; Ji, L.; Jinduan, Z.; Zhongyi, Z.; Fupeng, W.; He, Y. Chinese J. Anal. Lab. 1990, 12 (5), 305-307.

[44]. Quanlin, Z.; Shaoyi, G. Chinese J. Spect. Lab. 1997, 14 (4), 88-93.

[45]. Hong-Yan, M. A.; Yun, W. Chinese J. Spect. Lab. 2000, 17 (1), 100-103.

[46]. Guien, Z.; Hong, C.; Suling, F. Chinese J. Anal. Lab. 1996, 24 (5), 539542 .

[47]. Guilan, S.; Yuting, L.; Zhe, X.; Xufeng, G.; Zengyu, Y. J. Shandong Inst Build. Mater. 1997, 11 (4), 326-329.

[48]. Chongqiu, J.; Fengyan, Z. Chinese J. Anal. Lab. 1994, 22 (10), 10161018

[49]. Hongyan, M. A.; Guang-Cai, Q. I. Metallurg. Anal. (China) 2001, 21 (4) 16-17.

[50]. Li-Hong, W.; Hui, Z.; Qiang, L.; Shu-Cun, L. Phys. Testing Chem. Anal. (Part B: Chem. Anal.) 2009, 9, 1072-1074.

[51]. Shan-Bao, Q.; Qing-Dong, W.; Chang-Mei, J. Phys. Testing Chem. Anal. (Part B: Chem. Anal.) 2009, 9, 1051-1055.

[52]. Xiao-Min, W.; Shen, C.; Jiao-Mai, P. Chem. J. Chinese Univ. 1991, 12 (9), 1181-1182.

[53]. Porter, H. D. J. Am. Chem. Soc. 1954, 76 (1), 127-128.

[54]. Pal, B. K.; Chakrabarti, A. K.; Ahmed, Md. J. Anal. Chim. Acta 1988, 206, 351-355.

[55]. Ahmed, M. J.; Islam, M. T.; Hossain, F. RSC Adv. 2018, 8 (10), 55095522.

[56]. Ahmed, M. J.; Afrin, A.; Rashid, M. Am. J. Anal. Chem. 2019, 10 (08), 316347.

[57]. Ahmed, M. J.; Islam, M. T.; Farhana, F. RSC Adv. 2019, 9 (44), 25609 25626

[58]. Jeffery, G. H.; Bassett, J.; Mendham, J.; Denney, R. C., Vogel's Textbook of Quantitative Chemical Analysis, ELBS of $5^{\text {th }}$ edition, John Wiley Sons Inc., 1989.

[59]. Parker, G. A. Analytical Chemistry of Molybdenum; Springer Berlin Heidelberg, 1983.

[60]. Mukherji, A. K. Aqueous Solutions of Zirconium and Hafnium. In Analytical Chemistry of Zirconium and Hafnium; Elsevier, 1970; pp 111

[61]. Pal, B. K.; Choudhury, B. Mikrochim. Acta 1984, 83 (1-2), 121-131.

[62]. Ojeda, C. B.; de Torres, A. G.; Rojas, F. S.; Pavon, J. M. C. Analyst 1987 112 (11), 1499-1501.

[63]. Ahmed, M. J.; Afrin, A.; Akhtar, Y. Am. J. Anal. Chem. 2019, 10 (11), 528561

[64]. Ahmed, M. J.; Stalikas, C. D.; Veltsistas, P. G.; Tzouwara-Karayanni, S. M.; Karayannis, M. I. Analyst 1997, 122 (3), 221-226.

[65]. Pal, B. K.; Ahmed, Md. J. U.; Chakrabarti, A. K. Analyst 1990, 115 (4), 439-443.

[66]. Sample Preparation Techniques in Analytical Chemistry; Mitra, S., Ed John Wiley \& Sons, Inc., 2003.

[67]. Sun, Y. C.; Yang, J. Y.; Tzeng, S. R. Analyst 1999, 124 (3), 421-424

[68]. Greenberg, E. A.; Clesceri, S. L.; Eaton, D. A., Standard Methods for the Examination of Water and Wastewater, $18^{\text {th }}$ edition, American Public Health Association, Washington D. C., 1992.

[69]. Chambon, P.; Lound, U.; Ohanian, E. WHO Guidelines for Drinking Water Quality, Recommendations, 2nd edition, WHO, Geneva, 1993.

[70]. Ternero, M.; Gracia, I. Analyst 1983, 108 (1284), 310-315.

[71]. Stahr, H. M. Analytical Methods in Toxicology, $3^{\text {rd }}$ edition, John Wiley and Sons, New York, 1991

[72]. Jackson, M. L. Soil Chemical Analysis, Prentice Hall, Englewood Cliffs, 1965.

[73]. Tunceli, A.; Turker, R. Microchim. Acta 2004, 144 (1-3), 69-74.

\section{(c) (1) (8)}

BY NC Copyright (c) 2021 by Authors. This work is published and licensed by Atlanta Publishing House LLC, Atlanta, GA, USA. The full terms of this license are available at http://www.eurjchem.com/index.php/eurjchem/pages/view/terms and incorporate the Creative Commons Attribution-Non Commercial (CC BY NC) (International, v4.0) License (http://creativecommons.org/licenses/by-nc/4.0). By accessing the work, you hereby accept the Terms. This is an open access article distributed under the terms and conditions of the CC BY NC License, which permits unrestricted non-commercial use, distribution, and reproduction in any medium, provided the original work is properly cited without any further permission from Atlanta Publishing House LLC (European Journal of Chemistry) No use, distribution or reproduction is permitted which does not comply with these terms. Permissions for commercial use of this work beyond the scope of the License (http://www.eurjchem.com/index.php/eurjchem/pages/view/terms) are administered by Atlanta Publishing House LLC (European Journal of Chemistry). 